\title{
The Rogue as an Artist in Patrick deWitt's The Sisters Brothers
}

\section{ABSTRACT}

This article explores Eli Sisters as a reinvigorated rogue who finds his artistic calling in Patrick deWitt's The Sisters Brothers, published in 2011. With the help of insights from narratology and genre theory, the article provides a textual analysis of Eli's discourse, perspective and behaviour. Eli casts a critical light on the senseless violence, unbridled greed, ecological devastation, and hyper-masculinity inherent to America's Frontier myth. As a reinvigorated rogue, he raises questions about what it means to be human and reflects upon morality. With hindsight, the rogue as an artist creates a generically hybrid narrative that parodically imitates and transforms the genre conventions of the Western and the picaresque tale. The article also draws attention to the power that Eli assigns to women in a story about male heroic conquest. These include otherworldly female figures from classical mythology and the brothers' mother.

Keywords: Patrick deWitt, The Sisters Brothers, the reinvigorated rogue, parody, genre border crossing. 
Eli Sisters, the protagonist in Patrick deWitt's highly acclaimed novel The Sisters Brothers, retrospectively unfolds his tale about the epic journey of the Sisters siblings during the 1850s California Gold Rush. Eli creates a generically hybrid narrative in which he combines the fictional conventions of the Western and rogue tale with figures and motifs from classical mythology. Eli's written personal testimony disrupts the ontological borders between different storyworlds. In the course of Charlie and Eli's adventure, events that belong to the profane space and historical time of the popular Western and picaresque tale are interrupted by incidents that allude to mythical space and sacred time. The professional gunfighters are at the mercy of powerful female supernatural agents that confront the brothers with their moral responsibility. It is the Fates who intrude into the lives of these outlaws so as to allocate cosmic justice. They control the metaphorical thread of life and interfere with the journey's intended sequence of events. In this way the three Fates subvert the linear travel adventure plot, the clear teleology, and historical time of the traditional Western and rogue tale. They also bring a sudden halt to comic scenarios that are typical of the latter genre, for the main characters are subjected to fearsome and even tragic events caused by various supernatural beings.

The Sisters brothers have a bad reputation as ruthless killers, although Eli clearly has more in common with the amoral rogue. $\mathrm{He}$ regularly displays the rogue's positive traits, such as the capacity to be gentle, charming and clever. He is, however, in many ways distinct from the traditional rogue. He shows personality traits of a reinvigorated rogue who displays a high degree of sincerity, empathy, vulnerability and sentimentality. It is thanks to his ethical sense that he will give the plot of his life an unexpected twist.

Eli Sisters is the author's medium to creatively reinterpret the historical past. He composes a story in which he throws a critical light on the senseless violence, unbridled greed, ecological devastation, and hypermasculinity inherent in America's Frontier myth. ${ }^{1}$ In addition, Eli reflects on aspects of human nature that are both timeless and typical of our own age. He overtly and systematically expresses his concern about people's isolation, individualism, shallow materialism, and lack of a moral sense.

1 Like E. L. Doctorow's postmodern novel Welcome to Hard Times (1960), deWitt's parody of the Western is used to satiric ends. In A Poetics of Postmodernism, Linda Hutcheon states that Doctorow underlines "the power of money, greed, and force on the frontier." She adds that the American novelist's post-Western "forces us to rethink and perhaps reinterpret history, and he does so mainly through his narrator, Blue, who is caught in the dilemma of whether we make history or history makes us" (134). 
The sensibilities which Eli displays are strikingly prominent in contemporary fiction. Thus Mary K. Holland detects in present-day American literature "sentimental deployments of language as an essentially humanist endeavor" and a "crucial shift toward affect and human feeling" (7-8). Peter Boxall recognizes in twenty-first century fiction "a new ethical relationship to history, a new sense of a responsibility to material historical forces" (41-42). In her study of contemporary British fiction, Vera Nünning similarly discovers a return to ethical questions (254).

At the same time, literary and cultural theorists emphasize that moral seriousness is not necessarily absent in formally experimental postmodern fiction. According to Hans Bertens, early twenty-first century fiction more openly displays "an affirmative, humanist strand" of postmodernism (306). Bertens asserts that many contemporary writers both rely on postmodern metafictional self-reflexivity and overtly signal a serious moral commitment (308). Irmtraud Huber confirms that "although the new generation of writers sets out to do something different, the move is not so much against postmodernism but through and beyond it" (46).

The Canadian novelist Patrick deWitt clearly follows the tradition of (Canadian) postmodern literature in contesting master narratives and creating generic instability by means of parody. In Undermajordomo Minor, he imitates and transforms the fictional conventions of the Gothic novel. He parodies the comedy of manners in his latest novel French Exit. His experiment in The Sisters Brothers with the rogue tale, the Greek epic and the Western genre, which is a modern variation on Greek hero myth, is reminiscent of Robert Kroetsch's The Studhorse Man (1969). Like Kroetsch, deWitt relies on the figure of the rogue in order to retell a story and revivify various genres.

Eli Sisters gradually becomes aware of his need and desire for sincere communication, not only with Charlie but also with the characters he encounters on the road. Irmtraud Huber notices that contemporary literature often addresses people's isolation and focuses on communicative bonding. Characters establish connections through intersubjective dialogue and storytelling. Mary K. Holland observes that, since "the narrative turn" in the 1980s, prose fiction has increasingly emphasized the individual's interaction with others through storytelling as essential to human existence (1). Fictional characters are depicted as storytellers who resist narrative models imposed on them and actively construct their "narrative identities" (Meretoja, The Narrative Turn 225).

Eli, who uses language to create meaningful relationships, finally realizes that he possesses a gift for storytelling and a poetic sensibility. His fictional autobiography largely deals with this process of self-discovery. Eli's artistic vocation fits into the tradition of picaresque adventure novels 
by, for example, Joyce Cary and Iris Murdoch. Ana Raquel Lourenço Fernandes mentions Cary's The Horse's Mouth (1944) and Murdoch's Under The Net (1954) in which the rogues are "creators in pursuit of a new, original work" (57). In The Horse's Mouth, the protagonist is a painter "who seeks new ways of giving meaning to the world"; in Under The Net, the rogue is "an aspiring writer, whose artistic quest rouses the moral, aesthetic, and epistemic uncertainties of the time" (Fernandes 220).

This article examines Eli Sisters as a rogue who casts a critical light on the Gold Rush, raises questions about what it means to be human, and reflects upon morality. In addition, the first-person narrator will be treated as deWitt's medium for literary experiment. Eli is the artist who creates the roguishly subversive narrative in which the boundaries of various genres are deliberately transgressed. Eli parodically disrupts the hierarchy between "high" and "low" literary genres and freely combines the lyrical, epic, and dramatic mode. He is also the inventor of an epilogue that subverts the conventional ending of both the Western and the picaresque tale.

The Sisters Brothers revolves around the adventurous journey and strange twist of fate in the lives of Eli and Charlie Sisters. These notorious outlaws and gunfighters work as contract killers for their employer, the Commodore. The latter sends them on a mission to find and kill Hermann Warm, a lone prospector who invented a scientific formula with which to extract gold from a river. The powerful and greedy Commodore, also known as "a killer and bully" (deWitt, The Sisters Brothers 194), ${ }^{2}$ wants the famous brothers to provide him with the fortune hunter's recipe. In their quest for Warm and his gold-finding liquid, Eli and Charlie are preceded by Henry Morris, the Commodore's scout. In 1851, the brothers depart on horseback from Oregon City and head for the wilderness of California.

Eli rarely foregrounds the written nature of his autobiographical narrative. He merely includes the following metafictional lines: "as will be shown in the proceeding pages" (184); "which I will now describe" (199); "the above-described mentality" (247). He more obviously creates a temporal and cognitive distance between his older and mature recollecting self and the experiencing "I." According to Ulrich Wicks, the "double perspective of the narrating 'I' and the remembered ' $\mathrm{I}$ ' is a crucial aspect of the narrative nature of picaresque from Apuleius' Golden Ass to Felix Krull and Die Blechtrommel" ("The Nature of Picaresque Narrative" 244). Dual focalization is a means for the narrator to depict and analyze his younger and ignorant self in the past and to emphasize "the difference

2 Patrick deWitt, The Sisters Brothers. London: Granta, 2011. All subsequent references in the text will be to this edition. 
between who he was then and what he is now" (Wicks, "Narrative Distance in Picaresque Fiction" 167).

In accordance with the conventional picaresque tale, the wiser narrator of The Sisters Brothers imposes an episodic structure on his narrative. With hindsight, Eli parodies his role as an outlaw in the classical Western. By portraying himself as a misfit in this storyworld of male heroic conquest, he liberates himself from the monologism and single world-view of the formulaic Western genre.

In deWitt's novel, the rogue as an artist retrospectively constructs his own individualized and highly introspective narrative identity. Eli is a realistic character who displays a rich psychic life and a complex psychology. He admits that he is capable of extreme violence when someone bullies him and even relishes his sudden "reversal to animal" (deWitt, The Sisters Brothers 246). Directly after, he feels a pang of shame about his capacity for savagery. He also gives the reader cause for amusement by revealing that he follows his mother's advice to masturbate in order to calm down.

Eli blames Charlie for manipulating him into violence and he increasingly manages to persuade Charlie not to get involved in senseless bloodshed. He is the one who convinces his older brother that it would be wrong to harm Warm and Morris. The latter unexpectedly chose to become Warm's friend and business partner. From Eli's moral point of view, these men aren't evil and he therefore urges Charlie not to shoot them, as it "would be more like killing children or women" (224). After having made Warm's acquaintance, Eli confides to him that he is used to assisting his brother in killing antagonists as "the thought of someone causing harm to" his brother is unbearable (262).

Being afraid of the Sisters brothers implies being afraid of death because the professional assassins have the bad reputation of killing their enemies before robbing them. By naming his main characters the Sisters brothers, deWitt contrasts the dread caused by the latter with the fear inspired by the three spinning Sisters from classical mythology. Clotho who spins the life thread, Lachesis who determines its length, and Atropos who cuts it, are part of the determinism of the Greek theological system. This classical triad may appear in literary texts in the guise of three witches. In Shakespeare's Macbeth, the three "weird sisters" are versions of the Fates. The adjective "weird" is derived from the Anglo-Saxon wyrd: "what happens to a person in life, fate, (bad) luck" ("Weird"). Shakespeare's tragedy revolves around the moral imperative "thou shalt not kill" and Macbeth, who stabbed king Duncan of Scotland, will inevitably be punished by the Fates. According to Margaret Visser "Shakespeare, however, insists on his characters' free will: the riddling fiends mislead, but they never force decisions" (12). 
Eli departs from realism when he describes mysterious characters who unexpectedly cross the brothers' path. These nonhuman forces belong to the epic realm of ancient myth and impose a moral order. They allude to Greek tragedy's normative and static world order and are a means for the rogue as an artist to deal with the subject of moral choice. Various otherworldly figures cause terrifying crisis events. Eli is deeply upset by a lone, weeping man who is strangely familiar to him and who keeps following the brothers. The uncanny apparition haunts him, for this person is most probably his murdered father. In a fit of violence, the latter severely broke his wife's arm and was subsequently killed by Charlie. Eli is convinced that his father was "a bad man" (deWitt, The Sisters Brothers 261) who "deserved to be killed" (66). Nevertheless, the repressed memory of the assassinated father returns as a ghost from the realm of the unconscious to disturb the brothers' peace of mind. Charlie is not affected by the stranger's distress, for he is not troubled by pangs of guilt. Throughout the entire narrative, the culprit is shown to be followed and punished unwittingly by the mythological Fates and Furies. His ill fortune will be the punitive measure for his deliberate patricide.

In Oregon Territory, Eli and Charlie enter a cabin that belongs to an "old witch" (31). To Vanja Polić, "the woman reminds of the three witches from Macbeth, or perhaps one of the three Moirae" (142). Eli's lyrical description of "a one-room shack, wispy cotton-smoke spinning from its chimney" (deWitt, The Sisters Brothers 28) indeed alludes to one of the mythological sisters who spins the web of fate. Considering the reference to her snapping "a piece of thin wire" (30), she must be Atropos who snips off the thread of life when someone's time comes to die. The relentless mythical crone significantly asks: "Do you fear I will kill you?" She knows everything about the brothers and "the dead men following behind" them (30). Charlie has reasons to be afraid, for the witch secretly administers to him a "heavy black liquid" (31), a potion of poisonous Atropa Belladonna berries that will make him suffer.

In the first "intermission" or intercalated dramatic scene, Eli experiences the visitation of a "terrible" girl who kills a real dog with a lethal dose of Belladonna (143). The otherworldly being informs Eli about her prophetic dream that contains "a protected man" and a dog that is in pain because it lost a leg. Her message predicts Charlie's predetermined fate, namely the unavoidable loss of his shooting hand. She describes herself in the dream as "tumbling lightly in circles" with the dog "spinning within the orb" beside her (144). The circle is a metaphor for fate and cyclic time (Visser 22) and "spinning" alludes to the Goddess who spins a person's life.

Eli turns out to be the protected man from the weird girl's prophecy because Mister Mayfield's bookkeeper saves him from being killed by 
trappers. Eli describes the bookkeeper with an image that refers to her mythical dimension, for she rolls her head "in slow circles" (deWitt, The Sisters Brothers 135). The woman presumably protects Eli from misfortune because he wishes to turn his back on a life dominated by greed, murder, and the need to be a "real" man. Instead, the protagonist allows his emotional intelligence and ethical awareness to gain the upper hand.

Charles Taylor calls the construction of one's own mode of existence an instance of "self-determining freedom" (27). Hanna Meretoja argues that "a sense of the possible-a sense of how things could be otherwise-is integral to moral agency and to the ethical imagination of individuals and communities. It has transformative potential" (The Ethics of Storytelling 4).

Space symbolism alludes to Eli's spiritual transformation that begins in the old witch's cabin. He crosses its "cursed threshold" (deWitt, The Sisters Brothers 38) in order to kill the grizzly bear that attacks his horse Tub. A curse is a fatum, "a thing said that must inevitably come to pass" (Visser 21). The threshold is a spatio-temporal symbolic border associated with "the breaking point of a life, the moment of crisis, the decision that changes a life" (Bakhtin 248). Eli's heroic decision to save a horse that "could not travel more than fifty miles in a day" (deWitt, The Sisters Brothers 6), while putting his own life at risk, is a liminal phase that initiates his transition from a familiar to a different type of manhood and selfhood. After this first stage in his rite of passage, Eli continues portraying himself as a protagonist whose experiences bear a similarity to those of the mythic hero. His quest plot overlaps to some degree with the narrative archetype as defined by Joseph Campbell:

Beyond the threshold, then, the hero journeys through a world of unfamiliar yet strangely intimate forces, some of which severely threaten him (tests), some of which give magical aid (helpers). When he arrives at the nadir of the mythological round, he undergoes a supreme ordeal and gains his reward. (245)

The grizzly bear ruins one of Tub's eyes, as a result of which Eli's horse is weakened. The protagonist feels great empathy with the suffering creature and reflects: "What a life it is for man's animals, what a trial of pain and endurance and senselessness" (deWitt, The Sisters Brothers 241). As a writer, he retrospectively muses over the effect of his faithful horse's death: "Many months later I became sentimental about him, and this feeling is still with me today, but at the time of his actual demise I experienced merely a lifted weight" (242). According to Richard Kearney, "this power of empathy with living things other than ourselves ... is a major test not just of poetic imagination but of ethical sensitivity" (139). 
Patrick deWitt's reinvigorated rogue also displays ethical sensitivity as a witness to the tragic chain of events suffered by the other main characters. The story's protected man is the only one who escapes being victimized by Warm's poisonous scientific formula. The narrative distinguishes Warm from Eli, for the prospector is a traditional rogue who puts his imagination to wrong use whereas Eli uses his imagination creatively to find ways of being human in the social world. Warm's scientific discovery is the product of an instrumental rationality that is indifferent to water pollution. He invents a mercury solution to extract gold ore from his claim. ${ }^{3}$ If successful, he intends to "sell the formula's secret ingredients for a million" (deWitt, The Sisters Brothers 192). The tragic episode contrasts the characters' allotted share in financial terms with their allotment of ill fortune as dictated by the three dark Sisters. Morris makes a misstep and falls into the highly toxic water, upon which Warm leaps after him. Morris's fall is fate masquerading as chance and it is fate which causes the men's downfall, to punish their greed and ecological destructiveness. The irony of fate, also known as cosmic irony, turns the so-called "River of Light" (195) into a river of darkness and death. This type of irony, which is closely connected to situational irony, implies that the outcome is incongruous with the characters' expectations.

Ulrich Wicks points out that a particular "grotesque or horrible incident" often occurs in picaresque fiction to deal with "the blackness and horror of the debased world" ("The Nature of Picaresque Narrative" 247). Eli reflects on the incident with the scientific formula as "a tangle of grotesqueness and failure" (deWitt, The Sisters Brothers 289). Warm and Morris are blinded by the shiny liquid metal and Eli compares Morris to "a piece of driftwood more than a man" (288). The terrifying and shocking event has a spiritually cleansing effect on Eli, for he is overwhelmed by a singular mix of pity and fear. He also realizes that he must be the man who is protected from harm in the weird girl's prophetic dream, for he ends up as the lucky one who departs in one piece from the wilderness of California.

The girl's dream about the three-legged dog predicted an omen of bad fortune in Charlie's life. Apparently by accident, he spills Warm's caustic

3 This process was introduced in Northern California at the end of the nineteenth century. It was responsible for the serious contamination of the soil, groundwater, rivers and lakes. Dalberg Global Development Advisors report the devastating effects of liquid mercury today in the Amazon region, specifically in the context of the new gold boom (Dalberg Global Development Advisors). In a similar vein, Human Rights Watch documented the harmful effects of mercury in artisanal and small-scale gold mining in Africa and the Philippines. 
substance on his shooting hand. However, it must be fate, the engineer of situations, which plays cruel tricks and causes the unexpected reversal of the outlaw's fortune. Charlie loses the traditional Western hero's "fully coherent male body" (Mitchell 167). A sign of his merited misfortune, his ruined hand will finally tame and degrade the sharpshooter.

In the following episode, it becomes clear that Charlie's shooting hand is destined to be amputated. The brothers return to Mister Mayfield's hotel in California in order to collect a hidden pile of money and gold. Yet the hotel is burnt down and the men are unexpectedly overpowered by Mayfield's "whores," the avenging Furies in human form. Eli poetically describes the smoke that surrounds the hotel as "wriggling ghost-snakes" (deWitt, The Sisters Brothers 303), for the infernal goddesses of the Underworld have snakes entwined in their hair. The chthonic deities of vengeance severely punish the wicked brother, as they did with Orestes who committed matricide in Aeschylus' The Oresteia. In Beyond Fate, Margaret Visser mentions the family as the special province of the Furies, the agents of the Fates. Matricide or patricide were viewed as the most heinous of crimes and one who killed a member of his own family was punished by "a pack of Furies, the Angry Ones, for having blood on his hands" (Visser 52-53).

Eli literally refers to an angry "pack" of whores who look down on the brothers "with scandal and outrage." They exclaim: "These bastards. Let's get them" (deWitt, The Sisters Brothers 305). The Erinyes, who possess superhuman strength, pin the brothers to the ground. The men are incapable of movement and one of the Furies mercilessly grinds her heel into Charlie's damaged hand, thus making sure that it will never heal. After this tragic episode has been brought to a close, Eli inserts another "intermission" into his narrative. In the second dramatic scene, "the peculiar girl" from the previous visitation appears to Eli with her dress hem "spun in a wheel" (308). The supernatural being tries to kill Charlie with a lethal dose of "black granules" or Belladonna but Eli saves his beloved brother by preventing him from drinking the potion.

Eli commits another heroic deed as soon as the brothers are back in Oregon City. He had made the conscious decision beforehand that murdering the Commodore would be "the final era of killing in [his] lifetime" (243). The rich and very influential Commodore has a pernicious influence "in every corner of the country" (316). Eli invents a scheme and proves his mettle by single-handedly drowning the villain in his bathtub while having all his "weight upon him" (317). This way, the rogue tricks the Commodore's followers because there is no bloodshed. More importantly, wily Eli proves that his so-called weakness in the context of the Western, his being overweight, can be turned into a strength. 
Eli's archetypal quest for personal identity revolves around his pursuit of happiness and his genuine wish to lead a virtuous existence. Thanks to the guidance of the Fates, Eli discovers that his hands are made to write creatively. After the first stage in his initiation process, he says: "I blew out the candle and stared once more at my ghostly hands. When they began to tingle, I wondered about the curse from the gypsy-witch's shack. When would it come to bloom, if ever? What form would it take?" (81). The image of his "ghostly hands" most probably connotes his unexplored creative imagination, for in the end he will become an artist instead of an honest shopkeeper.

In the context of Eli's process of emotional and spiritual growth, it is not only the powerful female characters who incarnate the ancient Fates and Furies that play an important role. While travelling on the road of life, the brothers also encounter real-life characters that have a story to tell. Some of these characters are women who typically populate the Western. Charlie uses (what seem to be mere) prostitutes to satisfy his basic needs, whereas Eli genuinely desires to establish with these women a relationship based on kindness, intimacy and trust. He deals with all the women he meets as unique individuals with whom he engages in a dialogue.

In contrast to Charlie, Eli cares very little about material gain. $\mathrm{He}$ willingly gives part of his spoils to the women who work in hotels and to a needy boy who the brothers encounter on the road. In addition, he is obviously more interested in digging out his own and other people's hidden sadness and suffering than in excavating gold. A case in point is his reaching out to Warm. He listens to the prospector's life story, which turns out to be that of a traditional rogue whose maturation ends with his being a scientific inventor. Thanks to their intersubjective dialogues, Eli gains insight into his ultimate calling. Warm is impressed by Eli's ability to transform mental images into story material. He compliments him by saying "touch of the poet in you, Eli" (261), which is Warm's way of referring to the protagonist's artistic sensibility.

As an artist, Eli relies on the critical and creative dimension of language to gain (self-) understanding. He parodies his role in the traditional Western by using a discourse that is incongruously eloquent or high for a character of low origin. As Vanja Polić remarks, "Eli's delicacy and elegance of phrase as well as his thought processes immediately strike the reader as discordant with his vocation of a gunslinger" (138). His tone of elevated seriousness is very strange indeed in the storyworld of both the Western and the traditional picaresque tale. When he expresses his feelings to the female bookkeeper at Mister Mayfield's hotel, Eli is clearly astonished by his lofty and lyrical discourse: "'Your laughter is like cool water to me,' I said. I felt my heart sob at these words, and it would not have been hard to summon tears: Strange" (deWitt, The Sisters Brothers 137). 
Eli is a sophisticated narrator who also displays eloquence in dealing with the ethical aspect of human behaviour. This is more than a rhetorical trick to arouse the readers' sympathy, for interpersonal dialogue and connection are essential to Eli. As stated earlier, his creative, sentimental deployment of language, the deliberate shift towards human feelings, moods and emotions, is typical of many narrators and characters in contemporary fiction.

Eli slowly discovers his free will and capacity to redefine himself. He used to be a follower of his extremely violent and manly brother, yet becomes a self-assertive hero who makes the moral decision to improve himself. He liberates himself from a pre-determined existence as soon as he makes the conscious decision that he wants to lead himself (302). Thus the outcome of Eli's spiritual journey is the result of his freely chosen destination, which involves a different way of being and an alternative route. The protagonist's controlling power of reason becomes clear from his ethical decision to return to the parental home after many years of absence. The mother refused to see her sons as long as they chose to be killers rather than look for a decent job.

Eli's epilogue defies the conventional ending of both the Western and the picaresque tale. It explores the attachment plot between the mother and her children and thus once again satirizes the ideal of hyper-masculinity. The image of silver in the first line of the epilogue, " $t \mathrm{t}]$ here was silver in the dawn" (319), alludes to the moon as a symbol of feminine energy in a male-dominated world. It is far from coincidental that Mister Mayfield's female bookkeeper leads Eli to "a safe place" lit by the moon (131) in an earlier episode.

Eli's reunion with his mother is emotionally satisfying. Overwhelmed by love for his mother, Eli tells her: "I have missed you very much, Mother. I think of you so frequently, and I believe Charlie does, also'” (322). The outcome of his life story pleases Eli, mainly because finding his own fulfilment, equilibrium and love are essential to him. The image of the rope in Eli's lyrical description, "[n] ow she pulled me to her, hand over hand up my arm as though she were scaling a rope” (324), may connote the life-line that binds him to his mother.

Eli's epilogue accentuates the natural bond of love between mother and son. This is quite distinct from the classical Western, which rejects female authority and definitively takes boys away from their mothers. Jane Tompkins argues that "the Western is a gigantic coming-of-age plot in which the hero proves to himself and anyone who will pay attention that he isn't Mama's Boy anymore; he is a man" (144). The content of Eli's epilogue also differs from the traditional picaresque tale. With regard to the latter, Luigi Gussago remarks that "the connection between parent and 
child is rather unusual in the picaresque (dis)order of things, ... parents do not accommodate themselves to the requirements of their institutional roles: picaresque heroes are inevitably either orphans or undesired children" (153). DeWitt innovates the Western and the rogue tale by adding to his novel a morally satisfactory epilogue. In the alternative ending, which deals with the brothers' unexpected destination, Eli eulogizes the importance of family ties.

As a storyteller, Eli clearly assigns a prominent role to powerful women in a narrative that is supposed to revolve around heroic male conquest. This analysis has shown that various otherworldly female figures cross the ontological border between the Greek Underworld and the main characters' reality. These women variously punish, guide or protect the lawless Sisters brothers in the context of their epic journey. Eli never discloses the provenance or meaning of these intimidating female characters. ${ }^{4}$ The reader needs to deduce their potential significance and function from the figurative discourse with which Eli reconstructs the past. It is no doubt appropriate for the rogue as an artist in present-day fiction to deliberately subvert the reader's expectations by refusing to give in to the common desire for a closed interpretation.

\section{Works CiTED}

Bakhtin, Mikhail. The Dialogic Imagination. Four Essays by M. M. Bakbtin. Ed. Michael Holquist. Trans. Caryl Emerson and Michael Holquist. Austin: U of Texas P, 1981. Print.

Bertens, Hans. "Postmodern Humanism." Canadian Review of Comparative Literature/Revue Canadienne de littérature comparée (Sept. 2012): 299-316. Web. 18 May 2019.

Boxall, Peter. Trenty-First-Century Fiction. A Critical Introduction. New York: Cambridge UP, 2013. Print.

Campbell, Joseph. The Hero with a Thousand Faces. New York: Pantheon, 1949. Print.

Dalberg Global Development Advisors. Healthy Rivers. Healthy People. Addressing the Mercury Crisis in the Amazon. WWF Report (Nov. 2018): 1-47. Web. 28 May 2019.

4 DeWitt also explores the tension between determinism and free will in his tragedy of manners, French Exit. This novel contains two explicit references to the Fates: "Without speaking of it [Malcolm and Frances] both had the sense of being tested by the Fates" (93); "The Fates have done you this damage” (130). 
DeWitt, Patrick. French Exit. New York: Ecco, 2018. Print.

---. The Sisters Brothers. London: Granta, 2011. Print.

Fernandes, Ana Raquel Lourenço. What about the Rogue? Survival and Metamorphosis in Contemporary British Literature and Culture. Brussels: Peter Lang, 2011. Print.

Gussago, Luigi. Picaresque Fiction Today. The Trickster in Contemporary Anglophone and Italian Literature. Leiden: Brill Rodopi, 2016. Print.

Holland, Mary K. Succeeding Postmodernism. Language E Humanism in Contemporary American Literature. New York: Bloomsbury, 2013. Print.

Huber, Irmtraud. Literature after Postmodernism. Reconstructive Fantasies. Basingstoke: Palgrave Macmillan, 2014. Print.

Hutcheon, Linda. A Poetics of Postmodernism. History, Theory, Fiction. New York: Routledge, 1988. Print.

Kearney, Richard. On Stories. London: Routledge, 2002. Print.

Meretoja, Hanna. The Ethics of Storytelling. Narrative Hermeneutics, History, and the Possible. Oxford: Oxford UP, 2018. Print.

---. The Narrative Turn in Fiction and Theory. The Crisis and Return of Storytelling from Robbe-Grillet to Tournier. New York: Palgrave MacMillan, 2014. Print.

Mitchell, Lee Clark. Westerns. Making the Man in Fiction and Film. Chicago: U of Chicago P, 1996. Print.

Nünning, Vera. "Beyond Indifference: New Departures in British Fiction at the Turn of the $21^{\text {st }}$ Century." Beyond Postmodernism. Reassessments in Literature, Theory, and Culture. Ed. Klaus Stierstorfer. Berlin: Walter de Gruyter, 2003. 235-55. Print.

Polić, Vanja. "Sisters Brothers Pack Heat: or How the Sisters Fared in the West." Facing the Crises: Anglophone Literature in the Postmodern World. Ed. Ljubica Matek and Jasna Poljak Rehlicki. Newcastle upon Tyne: Cambridge Scholars, 2014. 128-46. Web. 7 May 2019.

Taylor, Charles. The Ethics of Authenticity. Cambridge: Harvard UP, 1992. Print.

Tompkins, Jane. West of Everything. The Inner Life of Westerns. New York: Oxford UP, 1992. Print.

Visser, Margaret. Beyond Fate. Toronto: House of Anansi, 2002. Print.

"Weird." Ldoceonline.com. The Longman Dictionary of Contemporary English. Web. 2 Aug. 2019.

Wicks, Ulrich. "Narrative Distance in Picaresque Fiction." College Literature 6.3 (Fall 1979): 165-81. Web. 18 Dec. 2017.

---. "The Nature of Picaresque Narrative: A Modal Approach.” PMLA 89.2 (Mar. 1974): 240-49. Web. 18 Dec. 2017. 
Hilde Staels is Associate Professor of English literature and literary theory at the University of Leuven in Belgium. As a visiting professor at Ghent University, she teaches a master course on contemporary English-Canadian fiction. Her publications mainly focus on the techniques and formal qualities of narrative fiction. In addition to her monograph and articles on Margaret Atwood's novels, she has published articles on the Canadian authors Michael Ondaatje, Carol Shields, AnnMarie MacDonald, Aritha van Herk, Barbara Gowdy and Rawi Hage. hilde.staels@kuleuven.be 